\title{
Saw Palmetto induces growth arrest and apoptosis of androgen-dependent prostate cancer LNCaP cells via inactivation of STAT 3 and androgen receptor signaling
}

\author{
YANG YANG $^{1}$, TAKAYUKI IKEZOE $^{2}$, ZHIXING ZHENG $^{1}$, HIROKUNI TAGUCHI $^{2}$, \\ H. PHILLIP KOEFFLER ${ }^{3}$ and WEI-GUO ZHU ${ }^{1}$
}

${ }^{1}$ Department of Biochemistry and Molecular Biology, Peking University Health Science Center, Beijing 100083, P.R. China; ${ }^{2}$ Department of Hematology and Respiratory Medicine, Kochi Medical School, Kochi University, Okohcho, Nankoku, Kochi 783-8505, Japan; ${ }^{3}$ Division of Hematology and Oncology, Cedars-Sinai Medical Center, UCLA School of Medicine, Los Angeles, CA, USA

Received April 16, 2007; Accepted June 21, 2007

\begin{abstract}
PC-SPES is an eight-herb mixture that has an activity against prostate cancer. Recently, we purified Saw Palmetto (Serenoa repens) from PC-SPES and found that Saw Palmetto induced growth arrest of prostate cancer LNCaP, DU145, and PC3 cells with $\mathrm{ED}_{50}$ s of approximately 2.0, 2.6, and $3.3 \mu \mathrm{l} / \mathrm{ml}$, respectively, as measured by mitochondrialdependent conversion of the the 3-(4, 5-dimethylthiazol-2-yl)2, 5-diphenyltetrazolium bromide (MTT) assay. Saw Palmetto induced apoptosis of LNCaP cells in a time- and dosedependent manner as measured by TUNEL assays. Also, Saw Palmetto increased the expression of p21 wafl and p53 protein in LNCaP cells. In addition, we found that Saw Palmetto down-regulated DHT- or IL-6-induced expression of prostate specific antigen in conjunction with down-regulation of the level of androgen receptor in the nucleus as measured by Western blot analysis. Moreover, Saw Palmetto downregulated the IL-6-induced level of the phosphorylated form of STAT 3 in LNCaP cells. Furthermore, Saw Palmetto inhibited the growth of LNCaP cells present as tumor xenografts in $\mathrm{BALB} / \mathrm{c}$ nude mice without adverse effect. These results indicate that Saw Palmetto might be useful for the treatment of individuals with prostate cancer.
\end{abstract}

Correspondence to: Dr Yang Yang, Department of Biochemistry and Molecular Biology, Peking University Health Science Center, 38 Xueyuan Road, Beijing 100083, P.R. China

E-mail:yangsh@bjmu.edu.cn

Abbreviations: SP, Saw Palometto; PSA, prostate specific antigen; AR, androgen receptor; DHT, $5 \alpha$-dihydrotestosterone; STAT 3, activated signal transducer and activator of transcription 3; IL-6, Interleukin-6; FBS, fetal bovine serum

Key words: Saw Palometto, PSA, prostate cancer, androgen receptor, STAT 3

\section{Introduction}

Androgens play an important role in both development and maintenance of the normal prostate as well as the initiation and progression of prostate cancer $(1,2)$. Androgen deprivation therapy remains the mainstay of prostate cancer treatment (2). Androgen receptor (AR) belongs to the steroid hormone subfamily of nuclear receptors and mediates the signal of androgens. AR is complexed in the cytoplasm to chaperone proteins that keep the receptor in a transcriptional inactive form. Upon binding to the ligands, AR dissociates from the chaperone and translocates to the nucleus where it binds to androgen response elements (AREs) and activates target genes such as prostate specific antigen (PSA) $(1,2)$.

PSA belongs to the kallikrein-like serine protease family; it is produced almost exclusively by prostate epithelial cells, and is used as a serum marker for diagnosis and progression of prostate cancer (3). The 5'-upstream promoter and enhancer region of the PSA gene contains several AREs to which ligand activated AR binds and induces expression of PSA (4-6).

Signal transducers and activators of transcription (STAT) are part of the signal transduction pathway of many growth factors and cytokines and are activated by phosphorylation of tyrosine and serine residues by upstream kinases (7). For example, signaling by IL-6 generally induces phosphorylation of STAT 3 (7). This signaling has been demonstrated to play a major role in tumor formation (8). Aberrant signaling by STAT3 is found in many types of malignancies, including multiple myeloma, head and neck cancer, breast cancer, and prostate cancer (9-13).

Herbs have been used for many centuries for treatment of cancer $(14,15)$. Use of these therapies has been dramatically rising in recent years in the United States (16). One of the herbal mixtures frequently used by individuals with prostate cancer is the Chinese herbal mixture denoted PC-SPES (17-24). It contains a partially extracted mixture of eight herbs: Dendrantherma morifolium, Tzvel; Ganoderma Lucidium, Karst; Glycyrrhiza glabra L; Isatis indigotica, Fort; Panax pseudo-ginseng, Wall; Rabdosia rubescens; 
A

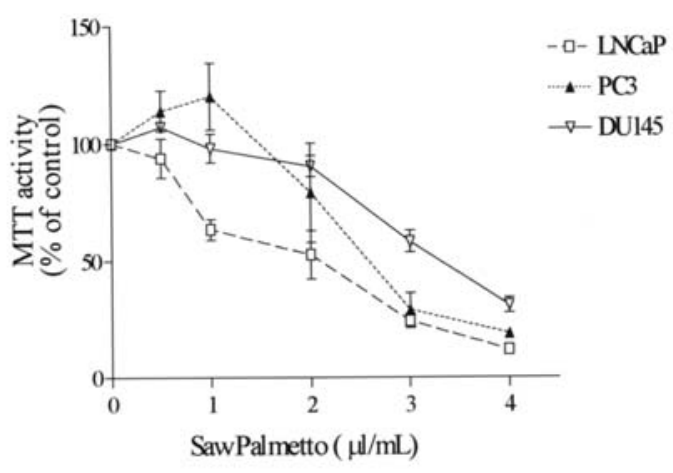

B

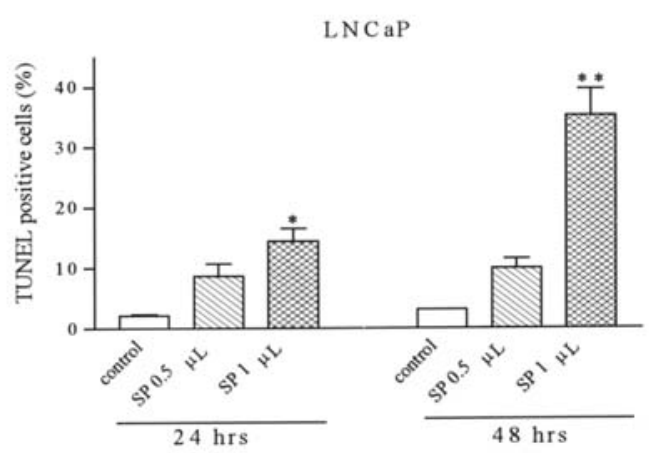

$\mathrm{C}$

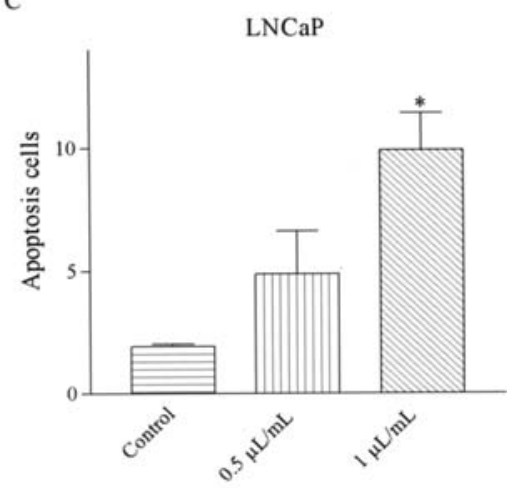

Saw Palmetto

D

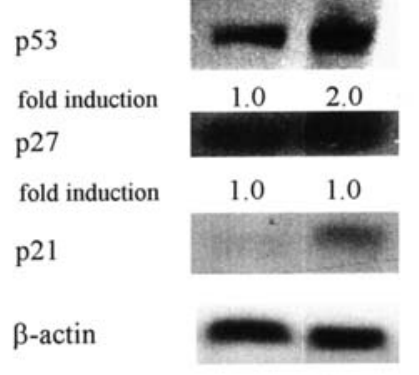

Figure 1. Effect of PIs on the proliferation and apoptosis of human prostate cells. (A) MTT assay. LNCaP, PC3 and DU145 cells (10 $/ \mathrm{ml})$ were plated in a 96well plate and cultured with various concentrations of Saw Palmetto (1-4 $\mu 1 / \mathrm{ml})$. After $48 \mathrm{~h}$, the cells were treated with $\mathrm{MTT}$ for $4 \mathrm{~h}$ at $37^{\circ} \mathrm{C}$, and $\mathrm{MTT}$ activity was measured. Results represent the mean \pm SD of 3 experiments performed in triplicate. (B) TUNEL assay. LNCaP cells were plated in a 24-well plate and cultured either with or without Saw Palmetto $(0.5$ or $1 \mu \mathrm{l} / \mathrm{ml})$; after 24 or $48 \mathrm{~h}$, apoptosis was measured by TUNEL assay. Results represent the mean \pm SD of 2 experiments performed in triplicate. (C) 7-AAD staining. LNCaP cells were incubated for 24 h either with or without Saw Palmetto (0.5 or $1 \mu \mathrm{l} / \mathrm{ml}$ ). Both floating and adherent cells were harvested, fixed with $70 \%$ methanol, stained with 7 -AAD, and subjected to flow cytometric analysis to determine the percentages of cells in pre-G1 phase (apoptotic cells). Results represent mean \pm SD of three experiments performed in duplicate. (D) Western blot analysis. LNCaP cells were cultured with either Saw Palmetto $(1 \mu 1 / \mathrm{ml})$ or control diluent. After $24 \mathrm{~h}$, cells were harvested and subjected to Western blot analysis. Membrane was sequentially probed with anti-p53, -p27kipl, -p21 wafl, and - 3 -actin antibodies, and band intensities were measured by densitometry and normalized for 3 -actin. SP, Saw Palmetto. ${ }^{*} \mathrm{p}<0.05,{ }^{* *} \mathrm{p}<0.005$.

Scutellaria baicalensis, Georgi and Serenoa repens (17-24). Previous studies showed that PC-SPES mediated an antiproliferative effect on prostate cancer cells in vivo and in vitro (16-25). In addition, recent clinical studies showed that PCSPES reduced prostate specific antigen (PSA) levels in more than $80 \%$ of individuals with prostate cancer $(26,27)$.

Saw Palmetto (Serenoa repens) is one of the components of PC-SPES. It has been studied exclusively in P.R. China and has been shown to possess anti-tumor activity. However, the mechanism by which Saw Palmetto inhibits growth of cancer cells remains to be fully elucidated. In this study, we found that Saw Palmetto inhibited the proliferation of prostate cancer cells. We also found that Saw Palmetto inhibited levels of PSA in conjunction with disruption of the AR signal pathway and inactivated STAT 3 signaling in LNCaP cells. Saw Palmetto might be useful for treatment of individuals with prostate cancer.

\section{Materials and methods}

Cell line. Prostate cancer LNCaP, PC-3, and DU145 cells were obtained from American Type Culture Collection (Manassas,
VA). They were maintained in RPMI-1640 with $10 \%$ fetal bovine serum (FBS).

Saw Palmetto. Saw Palmetto (Serenoa repens) was purified from PC-SPES. One capsule contains $400 \mathrm{mg}$ of powered herbal extracts. Stock solutions of Saw Palmetto were prepared by exposing these herbal extracts to $70 \%$ ethanol (1 capsule/ $1 \mathrm{ml}$ of $70 \%$ ethanol). For in vitro use, Saw Palmetto was diluted in RPMI-1640. An aliquot was used only once.

MTT assays. Cells $\left(10^{4} / \mathrm{ml}\right)$ were incubated with a variety of concentrations of Saw Palmetto (0-4 $\mu 1 / \mathrm{ml})$ for 3 days in 96well plates (Flow Laboratories, Irvine, CA). After culture, cell number and viability were evaluated by measuring the mitochondrial-dependent conversion of the tetrazolium salt, MTT (Sigma), to a colored formazan product, as previously described (28).

Assessment of apoptosis. Apoptotic cell death was examined by terminal deoxyribonucleotide transferase-mediated dUTP nick end labeling (TUNEL) method and 7-amino actinomycin$\mathrm{D}$ (7-AAD) staining. TUNEL assay was performed using the 
In situ cell death detection kit (Roche Molecular Biochemicals, Mannheim, Germany) as previously described (28). For 7AAD staining, cells were fixed in ice-cold methanol and then stained with 7-AAD (BD Biosciences, Bedford, MA) in the presence of RNase (Promega, Madison, WI). The DNA content of cultured cells was analyzed on a FACscan flow cytometer (Becton Dickinson, Mountain View, CA) by manual gating using Cell Quest software.

Western blot analyses. LNCaP cells were plated on 60-mm plates and incubated until $60-80 \%$ confluence, then the media was replaced with RPMI-1640 containing 10\% charcoalstripped FBS either with or without DHT $\left(10^{-8} \mathrm{M}\right)$ or IL-6 $(50 \mathrm{ng} / \mathrm{ml})$ and with either Saw Palmetto or control diluent (PBS). After incubation, cells were washed twice in PBS, whole cell lysates and nuclear extracts were prepared as previously described (29). Proteins were resolved by $4-15 \%$ SDS polyacrylamide gel, transferred to an immobilon polyvinylidene difluoride membrane (Amersham Corp., Arlington Heights, IL), and probed sequentially with antibodies. AntiAR N-20 (Santa Cruz Biotechnology, Inc., Santa Cruz, CA), anti-PSA C-19 (Santa Cruz), anti-p53 (Calbiochem, Darmstadt, Germany), anti-p27 ${ }^{k i p l}$ (sc-527, Santa Cruz), anti-p21 wafl (Calbiochem), anti-p-STAT 3 (Cell Signaling, Beverly, MA), anti-STAT 3 (Santa Cruz Biotechnology), and anti- $\beta$-actin antibodies (Santa Cruz) were used. The blots were developed using the enhanced chemiluminescence kit (Amersham Corp.).

Mice. Ten male triple immunodeficient BALB/c nude mice at 6 weeks of age were purchased from Japan Slc. Inc. (Shizuoka, Japan), and were maintained in pathogen-free conditions with irradiated chow. Animals were bilaterally, subcutaneously (s.c.) injected with $2 \times 10^{6} \mathrm{LNCaP}$ cells/tumor in $0.1 \mathrm{ml}$ Matrigel (Collaborative Biomedical Products, Bedford, MA). Mice were divided randomly into 2 groups of 5 mice each. Either Saw Palmetto (10 mg/kg/mouse) or control diluent was administered orally five times a week. The dose of Saw Palmetto was determined by our preliminary studies (data not shown). Tumors were measured every week with vernier calipers. Tumor sizes were calculated by the formula: a x b x c, where $a$ is the length, $b$ is the width and $c$ is the height in $\mathrm{mm}$. At the end of the experiment, animals were sacrificed by $\mathrm{CO}_{2}$ asphyxiation and tumor weights were measured after their careful resection. Tumor tissue was collected for analysis.

Measurement of PSA in mice. Blood was withdrawn from mice several hours before sacrifice. Serum levels of PSA were measured by immune assay employing the Hybritech Access (Beckman Coulter, Inc., Chaska, MN) according to the manufacturer's protocol.

Histology. Tumors were fixed for $12 \mathrm{~h}$ in $10 \%$ neutral buffered formaldehyde after sacrifice, tissue blocks were embedded in paraffin, and hematoxylin and eosin-stained sections were examined by light microscopy.

Statistical analysis. The difference between 2 groups under multiple conditions was assessed by one-way analysis of variance (ANOVA) using PRISM statistical analysis software (GraphPad Software, San Diego, CA). The non-parametric
Mann-Whitney U test was performed to assess the difference between 2 groups in the in vivo studies.

\section{Results}

Effect of Saw Palmetto on proliferation of prostate cell lines. To explore the anti-proliferative effects of Saw Palmetto, prostate cancer cell lines (LNCaP, DU145, PC3) were cultured in the presence of various concentrations of Saw Palmetto $(0-4 \mu \mathrm{l} / \mathrm{ml}, 48 \mathrm{~h})$. Saw Palmetto effectively inhibited the growth of LNCaP, DU145, and PC3 cells with the effective dose that inhibited $50 \%$ growth $\left(\mathrm{ED}_{50} \mathrm{~s}\right)$ of approximately 2.0, 2.6 , and $3.3 \mu 1 / \mathrm{ml}$, respectively as measured by MTT assay on the third day of culture (Fig. 1A).

Saw Palmetto induced apoptosis of LNCaP cells. TUNEL assay was utilized to examine the pro-apoptotic effect of Saw Palmetto. Saw Palmetto induced apoptosis of these cells in a dose- and time-dependent manner (Fig. 1B); Saw Palmetto $(0.5 \mu \mathrm{l} / \mathrm{ml}$ or $1.0 \mu \mathrm{l} / \mathrm{ml})$ induced a mean $8.7 \pm 2.0 \%( \pm \mathrm{SD})$ and $14.3 \pm 2.2 \%$ of the LNCaP cells to become apoptotic at $24 \mathrm{~h}$, which increased to a mean $9.9 \pm 1.6 \%$ and $35.1 \pm 4.4 \%$ at $48 \mathrm{~h}$, respectively $(\mathrm{p}<0.005)$ (Fig. 1B). In addition, the proportion of cells with fractional DNA content, a feature characteristic of apoptosis, was measured by 7-AAD staining using the LNCaP cells (Fig. 1C). Saw Palmetto $(0.5 \mu 1 / \mathrm{ml}$ or $1.0 \mu 1 / \mathrm{ml}$, $24 \mathrm{~h}$ ) induced a mean $4.9 \pm 1.7 \%$ or $9.9 \pm 1.5 \%$ of cells to become apoptotic $(\mathrm{p}<0.05)$ (Fig. 1C).

Effect of Saw Palmetto on expression of $p 21^{\text {wafl }}, p 27^{\text {kipl }}$, and p53 in LNCaP cells. The modulation of expression of the cell cycle checkpoint proteins, p2 $1^{\text {wafl }}$, p2 $7^{\mathrm{kipl}}$, and p53 were examined by Western blot analysis (Fig. 1D). LNCaP cells constitutively expressed wild-type p53 protein. Exposure of these cells to Saw Palmetto $(1 \mu 1 / \mathrm{ml}, 24 \mathrm{~h})$ increased their levels of $\mathrm{p} 53$ by 2 -fold compared with control cells. Whereas, Saw Palmetto $(1 \mu 1 / \mathrm{ml}, 24 \mathrm{~h})$ did not modulate the level of $\mathrm{p} 27^{\text {kipl }}$ in LNCaP cells (Fig. 1D). The level of p21 wafl protein was negligible in the untreated LNCaP cells; however, exposure of these cells to Saw Palmetto $(1 \mu \mathrm{l} / \mathrm{ml}, 24 \mathrm{~h})$ resulted in a dramatic increased level of p21 ${ }^{\text {wafl }}$ protein (Fig. 1D).

Effect of Saw Palmetto on level of PSA and AR protein. $\mathrm{LNCaP}$ cells cultured in the presence of $10 \%$ FCS constitutively expressed PSA and AR proteins in whole cell protein, and Saw Palmetto $(0.5 \mu \mathrm{l} / \mathrm{ml}$ and $1 \mu \mathrm{l} / \mathrm{ml}, 24 \mathrm{~h})$ down-regulated the level of PSA or AR by $90 \%$ or $80 \%$, respectively (Fig. 2A). Next, we explored the expression of PSA and AR proteins in cytoplasmic and nuclear proteins. As shown in Fig. 2B, Saw Palmetto $(1 \mu \mathrm{l} / \mathrm{ml}, 24 \mathrm{~h})$ down-regulated the level of PSA by $90 \%$ in cytoplasmic protein. Saw Palmetto $(1 \mu \mathrm{l} / \mathrm{ml}, 24 \mathrm{~h}) \mathrm{did}$ not modulate the level of AR expression in the cytoplasmic protein of LNCaP cells. Whereas, the expression level of AR protein was reduced by 0.4 -fold at the same dose in intranuclear levels (Fig. 2B).

Effect of Saw Palmetto on levels of DHT- or IL-6-induced PSA and AR protein. We further explored the effect of Saw Palmetto on levels of DHT- or IL-6-induced PSA and AR in cytoplasm and nucleus in LNCaP cells. In the presence of 
A

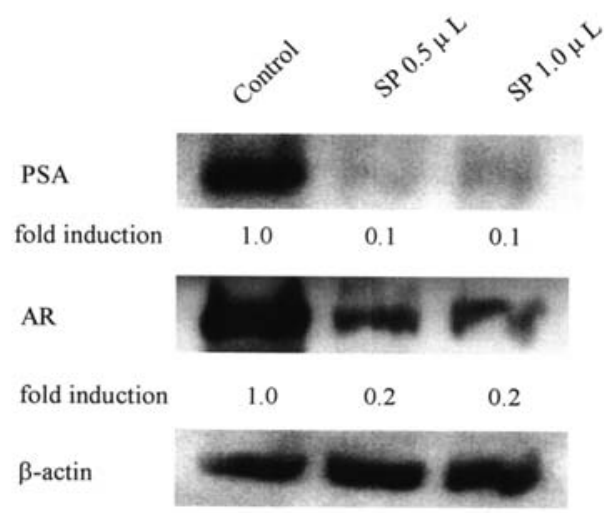

Whole cell lysates
B

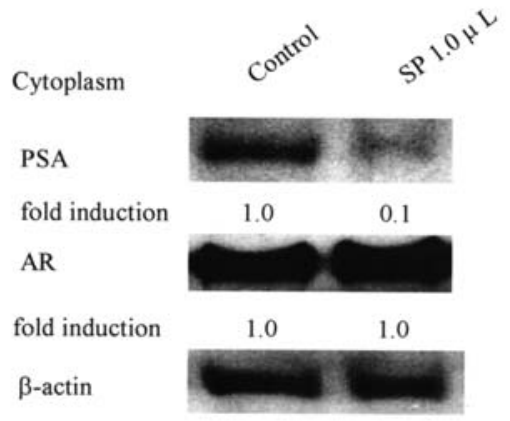

$\mathrm{C}$

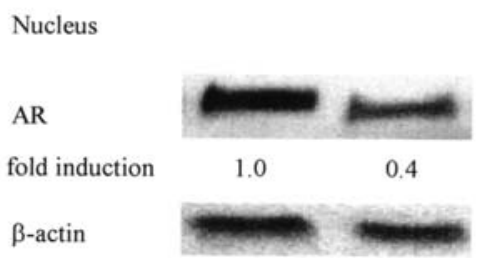

Figure 2. Effect of Saw Palmetto on the level of PSA and AR proteins. Western blot analysis. (A) LNCaP cells were cultured with either Saw Palmetto (0.5 $\mu 1 / \mathrm{ml}$ and $1 \mu \mathrm{l} / \mathrm{ml}$ ) or control diluent. After $24 \mathrm{~h}$, cells were harvested and subjected to Western blot analysis. The membrane was sequentially probed with anti-PSA, $-\mathrm{AR}$, and $-\mathrm{B}$-actin antibodies, and band intensities were measured by densitometry. (B) LNCaP cells were cultured with either Saw Palmetto (1 $\mu 1 / \mathrm{ml})$ or control diluent. After $24 \mathrm{~h}$, cytoplasmic proteins were extracted, subjected to Western blot analysis, and the membrane was sequentially probed with anti-PSA, -AR, and - $\beta$-actin antibodies. Band intensities were measured by densitometry. (C) LNCaP cells were cultured with either Saw Palmetto ( $1 \mu 1 / \mathrm{ml})$ or control diluent. After $24 \mathrm{~h}$, cells were harvested, and nuclear proteins were prepared and subjected to Western blot analysis, and the membrane was sequentially probed with anti-AR, and - $\beta$-actin antibodies. Band intensities were measured by densitometry. SP, Saw Palmetto.

A

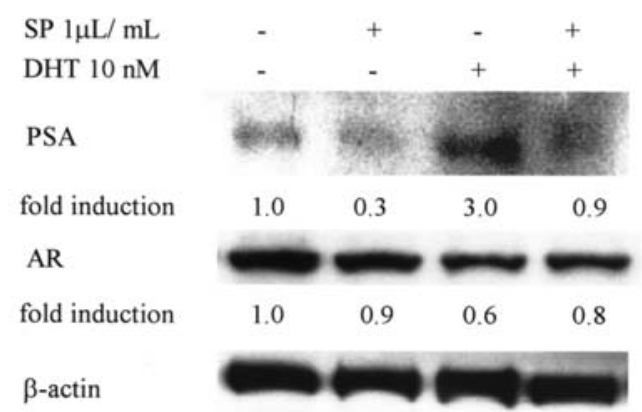

Cytoplasm

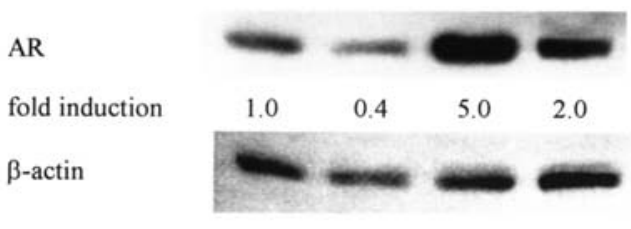

Nucleus
B

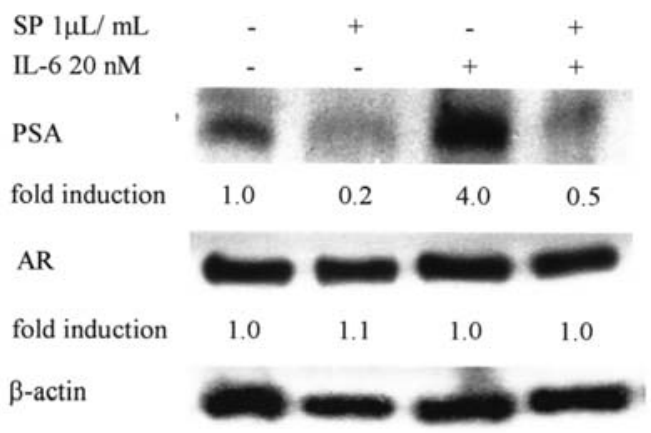

Cytoplasm

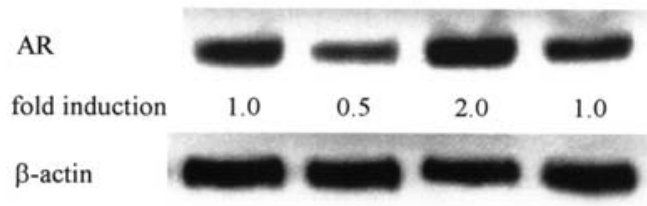

Nucleus

Figure 3. Effect of Saw Palmetto on levels of DHT- or IL-6-induced PSA and AR protein. Western blot analysis. (A) Effect of Saw Palmetto on levels of DHT-induced PSA and AR protein. LNCaP cells were cultured with either Saw Palmetto $(1 \mu \mathrm{l} / \mathrm{ml})$ or, either alone or in combination, DHT (10 nM) or control diluent. After $24 \mathrm{~h}$, cells were harvested and cytoplasmic and nuclear proteins were extracted, subjected to Western blot analysis, and the membrane was sequentially probed with anti-PSA, -AR, and - $B$-actin antibodies. Band intensities were measured by densitometry. (B) Effect of Saw Palmetto on levels of IL-6-induced PSA and AR protein. LNCaP cells were cultured with either Saw Palmetto ( $1 \mu 1 / \mathrm{ml})$ or control diluent. After $24 \mathrm{~h}$, cells were exposed to IL-6 $(20 \mathrm{ng} / \mathrm{ml})$ for $30 \mathrm{~min}$, harvested, and cytoplasmic and nuclear proteins were extracted, subjected to Western blot analysis, and membrane was sequentially probed with anti-PSA, -AR, and - $\beta$-actin antibodies. Band intensities were measured by densitometry. SP, Saw Palmetto. 
A

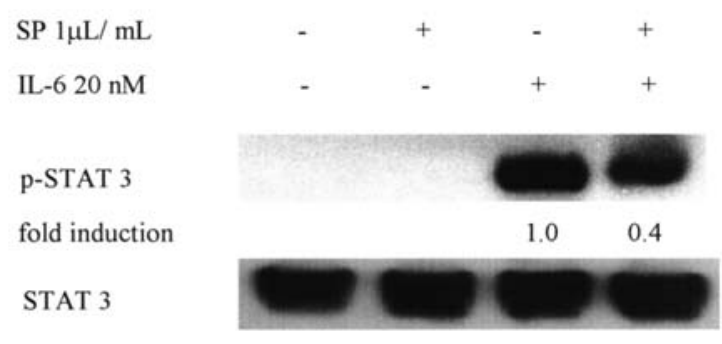

B

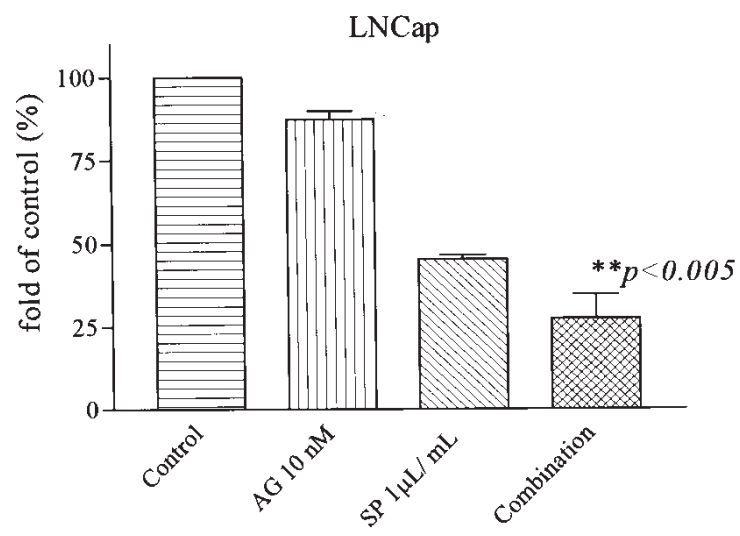

Figure 4. Effect of Saw Palmetto on STAT 3 activity in LNCaP cells. (A) Western blot analysis. LNCaP cells were cultured with either Saw Palmetto $(1 \mu \mathrm{l} / \mathrm{ml})$ or control diluent. After $3 \mathrm{~h}$, cells were exposed to IL-6 $(20 \mathrm{ng} / \mathrm{ml})$ for $30 \mathrm{~min}$, harvested, subjected to Western blot analysis, and membrane was sequentially probed with anti-p-STAT 3,-STAT 3 antibodies. Band intensities were measured by densitometry. (B) MTT assay. LNCaP cells $\left(10^{5} / \mathrm{ml}\right)$ were plated in 96 -well plates and cultured either with or without AG490 (10 nM). After $3 \mathrm{~h}$, cells were exposed to Saw Palmetto $(1 \mu \mathrm{l} / \mathrm{ml})$ for $48 \mathrm{~h}$, and their cell viability was measured by MTT assay. Results represent the mean \pm SD of 3 experiments performed in triplicate. SP, Saw Palmetto. ${ }^{* *} \mathrm{p}<0.005$.

DHT (10 nM, $24 \mathrm{~h})$, the expression of PSA protein was increased by approximately 3-fold and Saw Palmetto $(1 \mu 1 / \mathrm{ml}$, $24 \mathrm{~h}$ ) blocked DHT-induced levels of PSA in these cells by $70 \%$ in cytoplasm (Fig. 3A). Also, exposure of LNCaP cells to DHT decreased the level of AR in cytoplasm by $40 \%$ (Fig. 3A). At the same time, we extracted intra-nuclear protein and measured the level of AR. DHT (10 nM, $24 \mathrm{~h}$ ) increased the intra-nuclear levels of AR by approximately 5.0 -fold and the addition of Saw Palmetto decreased the DHT-induced nuclear level of AR by $60 \%$ (Fig. 3A), suggesting that Saw Palmetto interfered with DHT-induced nuclear translocation of AR. As shown in Fig. 3B, exposure of LuCaP cells to IL-6 $(20 \mathrm{nM}, 24 \mathrm{~h})$ increased PSA by approximately 4.0-fold. Exposure of Saw Palmetto $(1 \mu \mathrm{l} / \mathrm{ml}, 24 \mathrm{~h})$ blocked the IL-6induced level of PSA by $88 \%$ and Saw Palmetto $(1 \mu \mathrm{l} / \mathrm{ml}, 24 \mathrm{~h})$ did not affect the IL-6-induced level of AR in cytoplasm (Fig. 3B). In the meantime, we extracted the intra-nuclear protein and measured the expression of AR. IL-6 (20 nM, $24 \mathrm{~h}$ ) increased the intra-nuclear levels of AR by approximately 2.0-fold and the addition of Saw Palmetto decreased the IL-6induced nuclear level of AR by half (Fig. 3B). These data suggested that IL-6 did not affect AR nuclear translocation and Saw Palmetto decreased the IL-6-actived nuclear level of AR.
Effect of Saw Palmetto on IL-6-stimulated p-STAT 3 in LNCaP cells. We next investigated the effect of Saw Palmetto on STAT 3 signaling which is activated by IL-6. The level of the phosphorylated form of STAT 3 in the control LNCaP cells was negligible (Fig. 4A). LNCaP cells were serumstarved for $24 \mathrm{~h}$ and exposure of these cells to IL-6 $(20 \mathrm{ng} / \mathrm{ml}$, $30 \mathrm{~min}$ ) dramatically increased the level of the phosphorylated form of STAT 3. Pretreatment $(3 \mathrm{~h})$ of these cells with Saw Palmetto ( $1 \mu \mathrm{l} / \mathrm{ml}, 24 \mathrm{~h})$ blocked the IL-6-induced phosphorylation of STAT 3 by $60 \%$ (Fig. 4A). Saw Palmetto did not modulate basal and IL-6 stimulated levels of total STAT 3 (Fig. 4A).

Combination effect of Janus family of tyrosin kinase (JAK) inhibitor AG490 and Saw Palmetto on growth of LNCaP cells. We next studied the interaction of Janus family of tyrosin kinase (JAK) inhibitor AG490 and Saw Palmetto on growth of LNCaP cells. LNCaP cells were pre-incubated with AG490 $(10 \mathrm{nM})$ for $3 \mathrm{~h}$ and then exposed to Saw Palmetto $(1 \mu \mathrm{l} / \mathrm{ml})$ and cultured for 48 h. AG490 or Saw Palmetto alone inhibited the growth of $\mathrm{LNCaP}$ cells by $12.6 \pm 2.5 \%$ and $54.6 \pm 1.2 \%$ respectively. The combination of AG490 and Saw Palmetto inhibited the growth of LNCaP cells by $72.6 \pm 7.3 \%$ compared with control cells $(\mathrm{p}<0.005)($ Fig. 4B).

Effect of Saw Palmetto on LNCaP xenografts in vivo. We evaluated the ability of Saw Palmetto to inhibit the growth of LNCaP cells growing as xenografts in $\mathrm{BALB} / \mathrm{c}$ nude mice. Tumor volume was measured every week (Fig. 5A), and tumor weight was determined at autopsy (Fig. 5B). Saw Palmetto markedly suppressed the growth and weight of LNCaP tumors. As shown in Fig. 5A, the volume of LNCaP tumors in the mice who received Saw Palmetto was significantly decreased compared with control mice $(\mathrm{p}<0.05)$. In addition, the difference of mean tumor weights between these two groups was significant $(\mathrm{p}=0.02)$. The tumors from control mice weighed $98.6 \pm 36.0 \mathrm{mg}$. On the other hand, tumors from mice who received Saw Palmetto weighed only $32.8 \pm 22.7 \mathrm{mg}$ (Fig. 5B).

We next explored the ability of Saw Palmetto to decrease serum levels of PSA of LNCaP cells in vivo. After 4 weeks of treatment, blood was withdrawn from each mouse and serum levels of PSA were measured. As shown in Fig. 5C, the concentration of PSA in control cells was $5.3 \pm 2.2 \mathrm{ng} / \mathrm{ml}$ and in Saw Palmetto-treated cells was $1.8 \pm 2.0 \mathrm{ng} / \mathrm{ml}$. Serum levels of PSA were reduced by approximately $66 \%(\mathrm{p}<0.05)$ (Fig. 5C). Serum levels of PSA in normal mice at the same age were $<0.03 \mathrm{ng} / \mathrm{ml}$ (data not shown).

The tumors and organs of the BALB/c nude mice were fixed, stained, and viewed by light microscopy. The tumors from control mice showed a typical histological appearance of infiltrating, poorly differentiated adenocarcinomas of the prostate (Fig. 5D). Tumors from mice receiving Saw Palmetto had marked fibrosis and inflammatory cells such as giant cells (Fig. 5E). Organs from mice treated with Saw Palmetto did not show any changes compared with controls, including in their livers, kidneys, and spleens. During the study, all the mice were weighed each week. The mean weights of the experimental groups were statistically the same as those of the control mice (data not shown). 
A

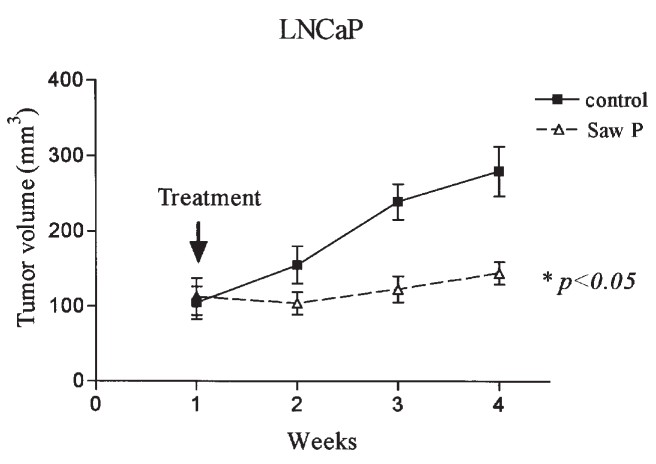

C

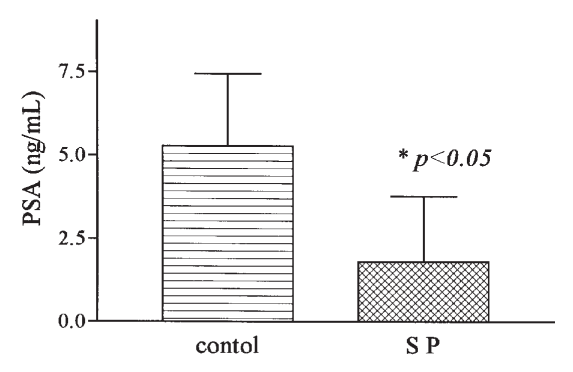

B
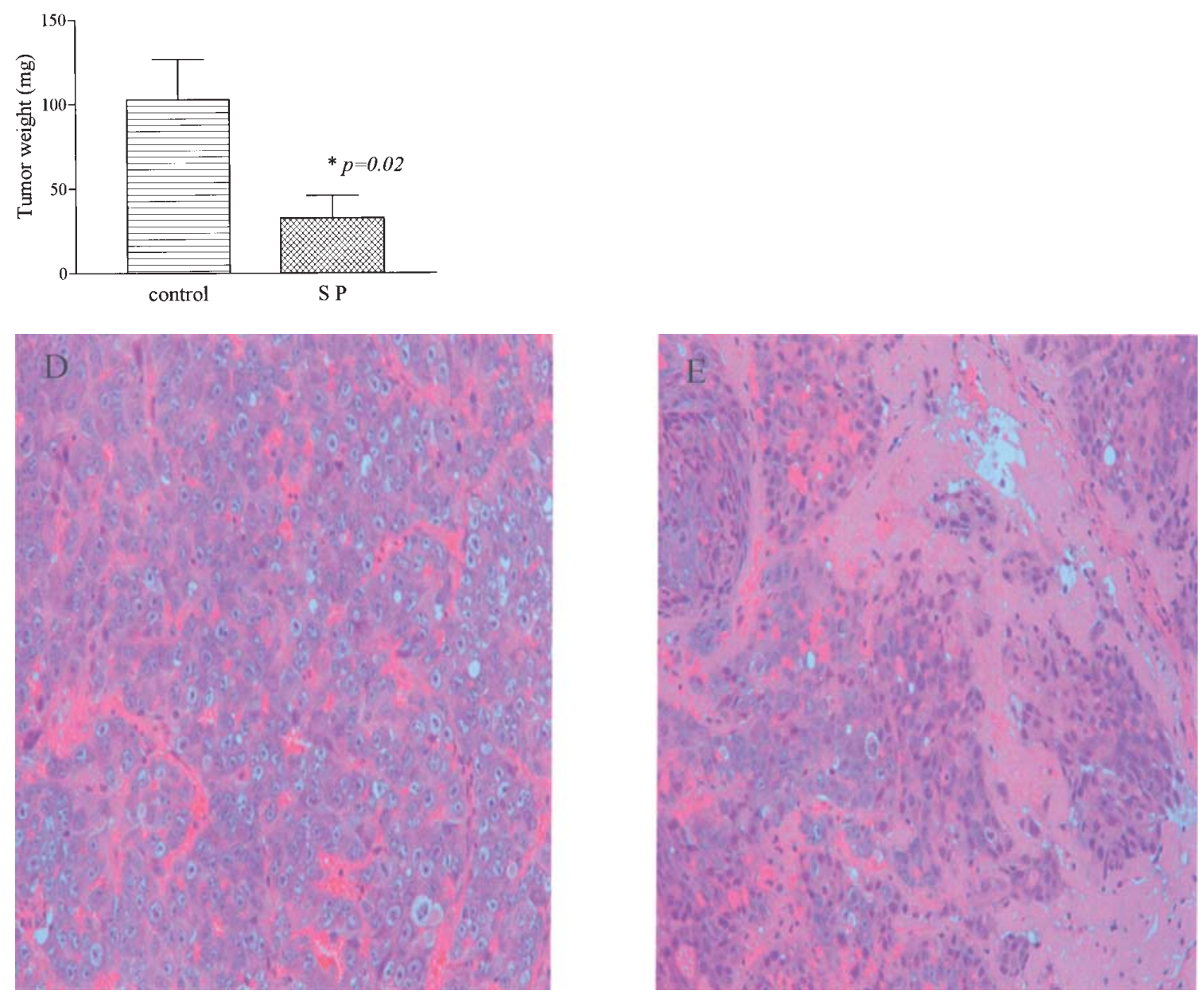

Figure 5. Effect of Saw Palmetto on growth of LNCaP tumors in nude mice. (A) Tumor volumes. LNCaP cells were injected bilaterally s.c. into BALB/c nude mice, forming two tumors/mouse. Saw Palmetto $(10 \mathrm{mg} / \mathrm{kg} / \mathrm{mouse})$ was administered orally five times a week. Control mice received diluent only. Tumors were measured every week. Each point represents the mean \pm SE of 10 tumors. (B) Tumor weights at autopsy. After 4 weeks of treatment, tumors were removed and weighed. Results represent mean \pm SE of tumor weights. Statistical significance of the differences was analyzed by Mann-Whitney U test. Bars, SE. (C) Serum levels of PSA. After 4 weeks of treatment, blood was withdrawn from each mouse and serum levels of PSA were measured. (D and E) Histology of LNCaP human prostate tumors from mice treated with Saw Palmetto in vivo. After 4 weeks of growth in nude mice treated either with or without Saw Palmetto, LNCaP tumors were removed, fixed in formalin, and stained with H\&E. (D) Control tumors from mice that received diluent displayed poorly differentiated adenocarcinoma (x200). (E) Tumors from mice treated with Saw Palmetto (10 mg/kg) five times a week for 4 weeks showed marked fibrosis and appearance of inflammatory cells such as giant cells (x200).

\section{Discussion}

Herbs have been used for many centuries for treatment of cancer. One of the herbal mixtures frequently used by individuals with prostate cancer is the Chinese herbal mixture denoted PC-SPES. Our previous study had shown that PCSPES inhibited the growth of prostate cancer cells and downregulated the basal and DHT-induced PSA expression in LNCaP cells (29). PC-SPES contains a partially extracted mixture of eight herbs, and which herb has the main effect in 
the treatment of prostate cancer is unclear. Recently, several investigators focused on the study of potent components of PCSPES. Rabdosia rubescens was reported to induce apoptosis of lung cancer cells and inhibit the growth of breast cancer cells $(30,31)$. Oridonin purified from Rabdosia rubescens induced growth inhibition and apoptosis of a variety of human cancer cells (32). Baicalin, a major component of PC-SPES, inhibited the proliferation of human cancer cells such as prostate cancer cell lines, breast cancer cell lines, myeloblastic leukemia cell lines and promyelocytic leukemia cell lines (33). In this study, we explored the effect of Saw Palmetto, one component of PC-SPES, on prostate cancer cells. We found that Saw Palmetto can effectively inhibit the growth of LNCaP, DU145, and PC3 cells and induced apoptosis of LNCaP cells in a dose- and time-dependent manner (Fig. 1B and C). Saw Palmetto down-regulated the level of PSA or AR in LNCaP cells (Fig. 2A). Also, Saw Palmetto down-regulated basal and DHT- or IL-6-induced PSA expression in cytoplasmic protein and AR expression in nuclear proteins in LNCaP cells (Figs. 2B and 3). These results suggested that Saw Palmetto is one of the representative components of PC-SPES on the treatment of prostate cancer. Saw Palmetto might inhibit LNCaP cell growth through blocking AR signaling.

Previous studies have demonstrated that STAT 3 signaling has a critical role in the tumor formation of prostate cancer $(34,35)$ and IL-6 treatment results in the activation of STAT 3 in prostate cancer cells (36). In this study, we found for the first time that Saw Palmetto down-regulated the IL-6-induced level of the phosphorylated form of STAT 3 in LNCaP cells (Fig. 4A). To block this pathway, a Janus family of tyrosin kinase (JAK) inhibitor AG490 was used and the proliferation of LNCaP was effectively inhibited in a dose-dependent manner (data not shown). The combination of AG490 and Saw Palmetto significantly inhibited the growth of LNCaP cells $(\mathrm{p}<0.005)$ (Fig. 4B). These results suggest that STAT 3 signaling also plays an important role in the survival of LNCaP cells and Saw Palmetto inhibits their cell growth via inhibition of STAT 3 signaling.

In summary, we found that Saw Palmetto is an important component of PC-SPES and active against prostate cancer cells in vitro as well as in vivo through inhibition of $\mathrm{AR}$ and STAT 3 signaling. Saw Palmetto may be useful as an adjunctive therapeutic agent for treatment of individuals with prostate cancer and other types of cancer in which AR or STAT 3 signaling is activated.

\section{Acknowledgments}

This study was supported in part by Grant-in-Aid from the Ministry of Education, Culture Sports, Science, and Technology of Japan. H.P.K. is supported by NIH Lung Cancer Spore grant, the George Harrison Foundation of America, the Cindy and Alon Horn Trust as well as the Inger Fund.

\section{References}

1. Quigley CA, DeBellis A, Marschke KB, el-Awady MK, Wilson EM and French FS: Androgen receptor defects: historical, clinical, and molecular perspectives. Endocr Rev 16: 271-321, 1995.
2. Gelmann EP: Molecular biology of the androgen receptor. J Clin Oncol 20: 3001-3015, 2002.

3. Polascik TJ, Oesterling JE and Partin AW: Prostate specific antigen: a decade of discovery - what we have learned and where we are going. J Urol 162: 293-306, 1999.

4. Pang S, Dannull J, Kaboo R, Xie Y, Tso CL, Michel K, deKernion JB and Belldegrun AS: Identification of a positive regulatory element responsible for tissue-specific expression of prostate-specific antigen. Cancer Res 57: 495-499, 1997.

5. Huang W, Shostak Y, Tarr P, Sawyers C and Carey M: Cooperative assembly of androgen receptor into a nucleoprotein complex that regulates the prostate-specific antigen enhancer. J Biol Chem 274: 25756-25768, 1999.

6. Schuur ER, Henderson GA, Kmetec LA, Miller JD, Lamparski HG and Henderson DR: Prostate-specific antigen expression is regulated by an upstream enhancer. J Biol Chem 271: 7043-7051, 1996.

7. Ihle JN: STATs and MAPKs: obligate or opportunistic partners in signaling. BioEssays 18: 95-98, 1996.

8. Darnell JE Jr: STATs and gene regulation. Science 277: 1630-1635, 1997.

9. Grandis JR, Drenning SD, Chakraborty A, Zhou MY, Zeng Q, Pitt AS and Tweardy DJ: Requirement of Stat3 but not Stat1 activation for epidermal growth factor receptor-mediated cell growth in vitro. J Clin Invest 102: 1385-1392, 1998.

10. Catlett-Falcone R, Landowski TH, Oshiro MM, Turkson J, Levitzki A, Savino R, Ciliberto G, Moscinski L, FernandezLuna JL, Nunez G, Dalton WS and Jove R: Constitutive activation of Stat3 signaling confers resistance to apoptosis in human U266 myeloma cells. Immunity 10: 105-115, 1999.

11. Buettner R, Mora LB and Jove R: Activated STAT signaling in human tumors provides novel molecular targets for therapeutic intervention. Clin Cancer Res 8: 945-954, 2002.

12. Epling-Burnette PK, Liu JH, Catlett-Falcone R, Turkson J, Oshiro M, Kothapalli R, Li Y, Wang JM, Yang-Yen HF, Karras J, Jove R and Loughran TP Jr: Inhibition of STAT3 signaling leads to apoptosis of leukemic large granular lymphocytes and decreased Mcl-1 expression. J Clin Invest 107: 351-362, 2001 .

13. Barton BE, Murphy TF, Adem P, Watson RA, Irwin RJ and Huang HS: IL-6 signaling by STAT3 participates in the change from hyperplasia to neoplasia in NRP-152 and NRP-154 rat prostatic epithelial cells. BMC Cancer 1: 19, 2001.

14. Risberg T, Lund E, Wist E, Kaasa S and Wilsgaard T: Cancer patient use of nonproven therapy: 5-year follow-up study. J Clin Oncol 16: 6-12, 1998.

15. Eisberg DM, Kessler RC, Foster C, Norlock FE, Calkins DR and Delbanco TL: Unconventional medicine in the United States: prevalence, costs, and patterns of use. N Engl J Med 328: 246-252, 1993.

16. Eisenberg DM, Davis RB, Ettner SL, Appel S, Wilkey S, Van Rompay M and Kessler RC: Trends in alternative medicine use in the United States, 1990-1997: results of a follow-up national survey. JAMA 280: 1569-1575, 1998.

17. Chen S: In vitro mechanism of PC-SPEC. Urology 58 (suppl 2A): 28-35, 2001

18. Darzykiewicz Z, Traganos F, Wu JM and Chen S: Chinese herbal mixture PC-SPES in treatment of prostate cancer. Int $\mathrm{J}$ Oncol 17: 729-736, 2001.

19. DiPaola RS, Zhang H, Lambert GH, Meeker R, Licitra E, Rafi MM, Zhu BT, Spaulding H, Goodin S, Toledano MB, Hait WN and Gallo MA: Clinical and biologic activity of an estrogenic herbal combination (PC-SPES) in prostate cancer. N Engl J Med 339: 785-791, 1998.

20. Taille A, Hayek OR, Buttyan R, Bagiella E, Burchardt M and Katz AE: Effects of a phytotherapeutic agent, PC-SPES, on prostate cancer: a preliminary investigation on human cell lines and patients. BJU Int 84: 845-850, 1999.

21. Moyad MA, Pienta KJ and Montie JE: Use of PC-SPES, a commercially available supplement for prostate cancer, in a patient with hormone-naive disease. Urology 54: 319-323, 1999.

22. Hsieh T, Chen SS, Wang X and Wu JM: Regulation of androgen receptor (AR) and prostate specific antigen (PSA) expression in the androgen-responsive human prostate LNCaP cells by ethanolic extracts of the Chinese herbal preparation, PC-SPES. Biochem Mol Biol Int 42: 535-544, 1997.

23. Hsieh TC, Ng C, Chang CC, Chen SS, Mittleman A and Wu JM: Induction of apoptosis and down-regulation of bcl-6 in mutu I cells treated with ethanolic extracts of the Chinese herbal supplement PC-SPES. Int J Oncol 13: 1199-1202, 1998. 
24. Kubota T, Hisatake J, Hisatake Y, Said JW, Chen SS, Holden S, Taguchi $\mathrm{H}$ and Koeffler HP: PC-SPES: a unique inhibitor of proliferation of prostate cancer cells in vitro and in vivo. Prostate: 42: 163-171, 2000.

25. Tiwari RK, Geliebter J, Garikapaty VP, Yedavelli SP, Chen S and Mittelman A: Anti-tumor effects of PC-SPES, an herbal formulation in prostate cancer. Int J Oncol 14: 713-719, 1999.

26. de la Taille A, Buttyan R, Hayek O, Bagiella E, Shabsigh A, Burchardt M, Burchardt T, Chopin DK and Katz AE: Herbal therapy PC-SPES: in vitro effects and evaluation of its efficacy in 69 patients with prostate cancer. J Urol 164: 1229-1234, 2000

27. Small EJ, Frohlich MW, Bok R, Shinohara K, Grossfeld G, Rozenblat Z, Kelly WK, Corry M and Reese DM: Prospective trial of the herbal supplement PC-SPES in patients with progressive prostate cancer. J Clin Oncol 18: 3595-3603, 2000.

28. Yang Y, Ikezoe T, Saito T, Kobayashi M, Koeffler HP and Taguchi H: Proteasome inhibitor PS-341 induces growth arrest and apoptosis of non-small cell lung cancer cells via the JNK/ c-Jun/AP-1 signaling. Cancer Sci 95: 176-180, 2004.

29. Ikezoe T, Chen SS, Yang Y, Heber D, Taguchi $H$ and Koeffler HP: PC-SPES: Molecular mechanism to induce apoptosis and down-regulate expression of PSA in LNCaP human prostate cancer cells. Int J Oncol 23: 1461-1470, 2003.

30. Liu JJ, Huang RW, Lin DJ, Peng J, Zhang M, Pan X, Hou M, Wu XY, Lin Q and Chen F: Ponicidin, an ent-kaurane diterpenoid derived from a constituent of the herbal supplement PC-SPES, Rabdosia rubescens, induces apoptosis by activation of caspase- 3 and mitochondrial events in lung cancer cells in vitro. Cancer Invest 24: 136-148, 2006.
31. Sartippour MR, Seeram NP, Heber D, Hardy M, Norris A, Lu Q, Zhang L, Lu M, Rao JY and Brooks MN: Rabdosia rubescens inhibits breast cancer growth and angiogenesis. Int J Oncol 26: $121-127,2005$

32. Ikezoe T, Chen SS, Tong XJ, Heber D, Taguchi H and Koeffler HP: Oridonin induces growth inhibition and apoptosis of a variety of human cancer cells. Int J Oncol 23: 1187-1193, 2003.

33. Ikezoe T, Chen SS, Heber D, Taguchi H and Koeffler HP: Baicalin is a major component of PC-SPES which inhibits the proliferation of human cancer cells via apoptosis and cell cycle arrest. Prostate 49: 285-292, 2001.

34. Barton BE, Murphy TF, Shu P, Huang HF, Meyenhofen M and Barton A: Novel single-stranded oligonucleotides that inhibit signal transducer and activator of transcription 3 induce apoptosis in vitro and in vivo in prostate cancer cell lines. Mol Cancer Ther 3: 1183-1191, 2004.

35. Barton BE, Karras JG, Murphy TF, Barton A and Huang HF: Signal transducer and activator of transcription 3 (STAT3) activation in prostate cancer: Direct STAT3 inhibition induces apoptosis in prostate cancer lines. Mol Cancer Ther 3: 11-20, 2004

36. Sanford DC and Dewille JW: C/EBPdelta is a downstream mediator of IL-6 induced growth inhibition of prostate cancer cells. Prostate 63: 143-154, 2005. 